\title{
Intermédialités
}

Histoire et théorie des arts, des lettres et des techniques

Intermediality

History and Theory of the Arts, Literature and Technologies

\section{Gardens of Things: The Vicissitudes of Disappearance}

\section{Anita Starosta}

Numéro 10, automne 2007

Disparaître

Disappearing

URI : https://id.erudit.org/iderudit/1005558ar

DOI : https://doi.org/10.7202/1005558ar

Aller au sommaire du numéro

Éditeur(s)

Centre de recherche sur l'intermédialité

ISSN

1705-8546 (imprimé)

1920-3136 (numérique)

Découvrir la revue

Citer cet article

Starosta, A. (2007). Gardens of Things: The Vicissitudes of Disappearance.

Intermédialités / Intermediality, (10), 147-163. https://doi.org/10.7202/1005558ar
Résumé de l'article

Cet article retrace la disparition de l'Union soviétique à partir d'objets esthétiques et quotidiens, en analysant l'organisation de valeurs éthiques et économiques qui marquent le prétendu monde post-soviétique. L’auteur propose une lecture du récit semi-biographique de Ryszard Kapuscinski, Imperium, des poèmes de Zbigniew Herbert, « Élégie pour le départ de la plume, de l'encre, de la lampe » et « Message de Monsieur Cogito ", ainsi que du film de Krzysztof Kieslowski, Sans fin (1984), en cherchant à interroger les médiations du changement historique et ses divers modes d'appréhension. L'auteure tente de montrer que les vicissitudes de la disparition remettent en question la notion de rupture historique, en rendant visibles les processus de renégociation et de reconstitution culturels. 


\title{
Gardens of Things: The Vicissitudes of Disappearance
}

\author{
Anita Starosta
}

T here is no shortage of means to confirm that the Soviet Union no longer exists. It is gone from contemporary maps, absent from current public discourse. Any wonder at this fact now can only be produced artificially-by shaking one's head, perhaps, or by recalling that, just a few years before the Soviet Union disappeared, "it seemed so impossible, inconceivable" that it ever would. One might even add a quiet "and yet!" With the passage of time, it has become increasingly difficult to muster the requisite incredulity.

The notion of disappearance comes with a set of tropes different from those offered by other accounts of historical change; it forces us to assert that radical change (must have) happened at the same time as it casts doubt on the possibility of such change. It propels thought backward in time, to a now irrecoverable moment. Disappearance necessarily evokes modes of appearance-at the same time as it calls that appearance into question. In La possession de Loudun, which

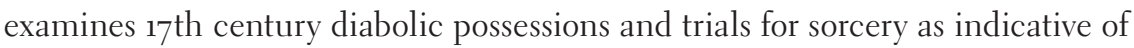
the shift from a vanishing paradigm of religion to an emerging paradigm of science, Michel de Certeau notes that "Loudun est un monde intermédiaire entre ce qui disparait et ce qui commence." He calls attention to the strangeness of history that manifests itself in transitional, intermediate times and places. "L'histoire," he concludes, "n'est jamais sûre." The lens of disappearance opens to view a dimension of history always hidden by narratives that, one way or another, manage to do away with the strange, the disorderly, and the uncertain.

One version of such available narratives relies on the trope of collapse. To speak of the fall or the toppling of the Soviet Union means to imagine the Soviet State as a concrete, material structure, both before and after its fall. The entity

1. Michel de Certeau, La possession de Loudun, Paris, Éditions Juillard, coll. "Archives", 1970, p. 9. 
may have fallen into pieces - but it is easy enough to locate the remains, to clean up the debris or to re-use it for something new. The ruins, after all, are chunks of the same matter of which the military bases, monuments, communist party buildings, schools, and factories had been made-even if, contrary to the literalist imagery of collapse, for every broken-down wall dozens of other structures remain in place. In any case, these are not actually expected to topple at all. Collapse is only a figure. But memories, social formations, hierarchies of power, and habits of thought do not fall as easily as deposed statues. Thus, in both the literal and the figural senses, "the fall of the Soviet Union" entails little actual ruin. For all its dramatic imagery, underneath the rubble, the trope of collapse offers a manageable sense of continuity.

Another account of history avows continuity to the point of error, as it gives up on change altogether, insisting that cultures and regions are basically stable throughout time. Here, no amount of revolution can shake the foundation of a people laid down by centuries. Such is the view of history in The Origins of Backwardness in Eastern Europe, for example, where "the great transformations that have taken place since 1500 have been channeled into streams whose banks were partially formed before that time" and where "underneath the structures that aped Western state institutions [...] the past remained to constrain the paths toward the future." ${ }^{2}$ Accounts like this one reduce cultural and political life to nothing more than people living out their fate and grant them neither agency nor consciousness of their own limitations-while the quality of this fate is closely tied to their place in an intricate global hierarchy. Failures of revolutions are evidence of an essential permanence.

The notion of transition, finally, only seems to make sense of the simultaneous continuity and change; instead, it merely contains the contradictions. It subjects everything to the rule of change, reassures that the contradictions will pass, as it holds out a normative ideal of development, the way things should be. Like the notions of radical change and radical constancy, "transition" does not explain historical change but is a way to manage it.

For de Certeau, the historian "a reçu de la société [...] une tâche d'exorciste. On lui demande d'éliminer le danger de l'autre."’ The dissolution of the Soviet Union-devoid as it may be of diabolical possessions of the kind witnessed in

2. Daniel Chirot, (ed.), The Origins of Backwardness in Eastern Europe: Economics and Politics from the Middle Ages until the Early Twentieth Century, Berkeley, University of California Press, 1989, p. 6 and 17.

3. Michel De Certeau, La possession de Loudun, p. 327. 
Loudun-has undergone its own share of exorcisms through the models of collapse, continuity, and transition. The notion of disappearance intervenes here to unsettle such narratives, to dictate a path of inquiry attentive to problems of materiality and mediation. Disappearance is, by definition, tied to the sensory sphere: it appeals to the senses at the same time as it shows them to be unreliable and betrays them. For, if an object has vanished from sight, how can one be sure it was once there to be seen to begin with? To take the disappearance of the Soviet Union literally is to ask by what means, and to what degree of certitude, one might verify it. It is not enough simply to observe that the object is nowhere to be found. To say that it has disappeared is, at the same time, to acknowledge its absence and to recall the modes of its past appearance, and thus to keep in mind two moments at once-the moment of the past (which is in doubt, by virtue of its pastness) and the moment of the present (which is marked by an absence). Disappearance puts into question not only the observer's senses, but also the very materiality of the disappeared object.

The lens of disappearance reveals a profound instability of knowledge even as it demands concrete evidence. The more one aims to approach a material ground of inquiry, the more elusive it becomes. As an amalgam of institutions, practices, physical structures, and geographical sites, the Soviet Union was material and immaterial at the same time, only partially perceptible; it thus seems especially difficult to apprehend as an object alongside others, occupying registers at once affective, epistemological, ethical. How might such an object have made its presence known and now make its absence felt? But the Soviet Union's status as an object is in question not merely because it was so vast, but precisely because it has disappeared. Evidence for its past existence must be appropriately trivial for the task, as material as possible, because that is where the Soviet Union made itself most concretely apprehensible: in urban landscapes; in school celebrations of Soviet anniversaries; in irony; in alcoholism; in poetry; in shame; in distorted history; in my father's drawer mysteriously filled with medals. If the Soviet Union is itself elusive, then it must be traced in its displacements onto other objectscaught in the act of organizing them, giving them a certain value, imposing specific constraints on thought and action, which also means creating the conditions of possibility of specific kinds of resistance.

Here, then, is one point of departure in my attempt to locate the Soviet Union. I must be six, at most seven, years old. I'm carrying a watermelon home, proudly resting it on my stomach as I embrace it with my arms. Having waited in a long line, I acquired it from the back of a truck that must have traveled far, from someplace very exotic. The Soviet Union was, actually, a mere hundred 
kilometers to the east, but that was inaccessible to me then; instead, I knew exactly what the watermelon was worth, and its value to me was determined by the entity just across the border.

The scene is appropriately ordinary and yet, inconveniently-because suddenly there was a watermelon in a place without watermelons, or because it happened to a child - it is also somewhat exceptional, difficult to extricate from a degree of nostalgia. In trying to explain that, to a child, the Soviet Union manifested itself in a certain value of a watermelon, I do not want to repeat the gesture of nostalgia for pre-1989 Eastern Europe expressed in renewed interest in Communist-era objects of daily utility. Despite its claims, Ostalgie-a German neologism that combines "nostalgia" with "the East" - is not a simple return to old values, but a form of commodification of memory, a retroactive attachment to a past that has already acquired a new value-as a quaint phenomenon marketable to museum curators, a belated resistance to the onslaught of the free market that has proven more alienating than Soviet-era artifice of planning and rationing. ${ }^{4}$ Ostalgie is an extreme response to the Soviet Union's disappearance, an attempt to recreate what has disappeared. It denies the temporal movement of the object-by fixing it in a point in time and then transporting it, as if intact, back into the present.

So there are pitfalls inherent in any attempt to account for disappearance through lived experience. Self-implication in the disappeared object and the very fact of its pastness distract from the task. The mere effort of reflecting on disappearance may easily be confused for nostalgia, which, as Svetlana Boym has put it, "tantalizes us with its fundamental ambivalence; it is about the repetition of the unrepeatable, materialization of the immaterial." 5 It is important to remain sober and keep the Soviet Union in focus as an object inflecting smaller objects, granting them specific values, because that is where it is most visible-even if that is also where it threatens to get lost again, amid all the affect.

Later, when I am older, my sister tries to weaken my resistance against leaving Poland. In America, she tells me, you can have all the watermelons (and peaches!) you want. I am not seduced, because my sense of dignity depends on disavowing the desire for mere abundance. Yet I leave all the same, and abundance is what awaits me. Watermelons, in the meantime, have become commonplace everywhere. This provisional object is elusive, it's temporality shifting.

4. See Charity Scribner, Requiem for Communism, Cambridge, Massachusetts, The MIT Press, 2003.

5. Svetlana Boym, The Future of Nostalgia, New York, Basic Books, 2001, p. xvii. 
I abandoned it at the same time as the worlds I traveled between were themselves changing. Historical time and lived time fail to converge in the watermelon, and yet that is where I turn.

The trivial memory of the watermelon is not a pure memory at all but is, retrospectively, shaped by familiar narratives of Soviet-era scarcity and isolation, tinged with flavors and textures of childhood. Thus, any attempt to locate a disappeared object is subject to over-determination, different sources providing an uncertain basis of knowledge. The story of the watermelon serves, nonetheless, to fix in place the incongruous references, sights, and sounds that flood the mind as I try to account for the disappearance of the Soviet Union. The detail of daily life puts in question the notion of historical continuity and, with it, the notion of historical rupture.

The story of the watermelon reveals two dimensions of history, perceptible only through the lens of disappearance. The first points to the instability of objects that may have already vanished and the disorientation they effect, subject as they are to overdetermination and displacement. This dimension poses a challenge to normative history because it confronts the specificity of objects-however different their degrees of materiality-with the threat of interchangeability. The second dimension turns attention to the fact that obsolescence is a complex process marked by the shifting values of things. Turning to aesthetic as well as ordinary objects that bear traces of the Soviet Union, I want to ground the Soviet Union's disappearance in the interplay of economic, aesthetic, and ethical values with which these objects have come to be invested. My watermelon is thus only a tentative ground. Accounting for disappearance requires attention to the uncertain, and not wholly verifiable, ways in which historical change is mediated.

\section{UNSTABLE OBJECTS}

It is one thing to admit the possibility that the autobiographical and the fictional may not exist in a relation of direct synchrony with the historical; it is another to make sense of the anachronisms. Ryszard Kapuściński, who as a foreign correspondent spent his life chronicling revolutions and upheavals, has no shortage of means to explain the changing worlds he observes: facts of the present moment mix with autobiographical reflections and details of witnessed lives. In Imperium, he follows the lifespan of the Soviet Union as it overlaps with his own. ${ }^{6}$ He tries to capture history as it is happening, and to render the ways in which public 
events inflect ordinary lives. Both in his own voice and in the voices of others, he juxtaposes the trivial and the tragic, attending to what can be seen and what remains invisible.

Kapuściński’s "first encounter with the empire" takes place in September 1939, when he is seven years old and his small town of Pinsk is ravaged by the beginnings of war. There, the Soviet Union makes itself known first in the dust and panic of refugees, and then, more ominously, in hushed voices, disappearances of his classmates, the foreign Russian alphabet inexplicably taught beginning with the letter "s"-for "Stalin." The changed tones in which adults now speak, the gravity of sounds after the curfew, the new rules in effect at school - this is how a child knows that his world has been altered. Kapuściński focuses attention not only on the new events; it is just as important to show how one knows something, how a new reality-all-encompassing and palpable, yet enigmatic-announces itself. In this way, he renders a mode of the Soviet Union's first appearance.

If it is possible to describe the encroachment of the Soviet Union in a more or less linear narrative, then its dissolution poses a greater challenge. Toward the end of Imperium, set in the 199os, the Soviet Union's vanishing proves as elusive as it is indisputable. In one of the last chapters, "Pomona of the Little Town of Drohobycz," Kapuściński travels through the Ukraine, with Drohobycz as his final destination. Along the way, he offers reports of events surrounding the republic's independence alongside descriptions of landscapes, cities, and people. Bronisława, an elderly woman from Lvov who survived the great hunger of the early 1930s, is one of the people he meets. Six of her ten children died. We learn that the famine was engineered by the Soviet state, which, attempting to force peasants to comply with collectivization, confiscated their crops. The scenes that follow are horrifying. A boy steals a fish from a market and is beaten to death by an angry mob. A father hangs his children and himself. Whole villages kneel down and wail for help whenever a train-prohibited from stopping in the countryside-goes by, carrying unknowing city dwellers. Millions of people die from hunger.

Bronisława seems to be "carrying an invisible weight," and speaks "as if what she is recounting had to do with her in some other incarnation, with which she, the one now sitting in front of me, has nothing in common. When I thought about her later," writes Kapuściński, "I was reminded of a sentence by old Paul Claudel: 'I look at my own former life as if it were an island receding on the horizon.' [...] Within us live several personae simultaneously, nearly indifferent 
toward one another, even contradictory."7 The point is not just that the Soviet Union, not easily shaken off with a declaration of independence, continues to mark people's lives. Bronisława's calm demeanor and cheerful gratitude for having survived testify to its passing as well. The simultaneous persistence and disappearance of the Soviet past are baffling, but the incongruity is, for the time being, well explained in the metaphor of multiple characters inhabiting a person, a time, a place.

If Kapuściński thrives on anachronism, there is a moment in Imperium when he seems to fall prey to his own formula; whether the breakdown is staged or genuine does not detract from its rhetorical force. This moment will be instructive in apprehending disappeared objects-a moment when Kapuściński attempts to force incongruous temporalities to cohere.

He goes to Drohobycz to pay homage to Bruno Schulz, the Polish Jewish writer and artist who earned his living teaching arts and crafts, and died at the hands of a Nazi officer during the war. Schulz's stories record a child's daily enchantments and struggles against the mundane, and are full of passages like this one, from "August" in Cinnamon Shops:

Adela returned from the market, like Pomona emerging from the flames of day, spilling from her basket the colorful beauty of the sun-the shiny pink cherries full of juice under their transparent skins, the mysterious black morellos that smelled so much better than they tasted; apricots in whose golden pulp lay the core of long afternoons. And next to that pure poetry of fruit, she unloaded sides of meat with their keyboard of ribs swollen with energy and strength, and seaweeds of vegetables like dead octopuses and squids - the raw material of meals with a yet undefined taste, the vegetative and terrestrial ingredients of dinner, exuding a wild and rustic smell. ${ }^{8}$

7. "Dźwigająca niewidoczny ciężar, mówi [...] jakby to, co opowiadała, dotyczyło jej, ale w jakimś innym wcieleniu, z którym ona, ta, która teraz siedzi przede mna̧, nie ma już właściwie wiele wspólnego. Kiedy myślałem o niej później, przypomniało mi sie zdanie starego Paula Claudela : 'Patrzę na swoje dawne życie jak na oddalającą się wyspę.' [...] W wielu z nas żyje jednocześnie kilka postaci, niemal obojętnych sobie, a nawet nawzajem sprzecznych." (Ryszard Kapuściński, Imperium, p. 285; our translation).

8. "Adela wracała w świetliste poranki, jak Pomona z ognia dnia rozżagwionego, wysypując z koszyka barwną urodę słońca-lśniące, pełne urody pod przejrzystą skórką czereśnie, tajemnicze, czarne wiśnie, których woń przekraczała to, co ziszczalo się w smaku; morele, w których mia̧ższu złotym był rdzeń długich popołudni; a obok tej czystej poezji owoców wyładowywała nabrzmiałe siłą i pożywnością płaty mięsa z klawiaturą żeber cielęcych, wodorosty jarzyn, niby zabite głowonogi i meduzy_surowy materiał o smaku jeszcze nie uformowanym i jałowym, wegetatywne i telluryczne ingrediencje 
Guided around Drohobycz by Alfred Szrejer, a former student of Schulz, Kapuściński is struck by the concreteness, and the size, of the town. "The life of the great Schulz passed in this little [...] triangle between Floriańska Street, Zielona Street, and the square by the bakery. Today, people can walk this distance in a few minutes, pondering the mystery of his extraordinary imagination."9

In Drohobycz, Kapuściński is not looking for traces of history but rather of a fiction that he has come to revisit as if a home. He ventures a question, even if he knows it to be absurd:

"Mr. Alfred, and where were the cinnamon shops?" Szrejer stops, with a mix of surprise, irony, and even disapproval in his eyes. "Where were the cinnamon shops, he repeats. But they were precisely in his imagination! That's where they glittered. That's where they smelled in that inimitable way!" Abashed as he is, Kapuściński persists. When Alfred points to an empty lot-"You see these dry twigs?"-he takes another chance: "Is this where the idiot girl Tłuja might have had her bed?" "Maybe she could have," the guide uncertainly concedes. ${ }^{10}$

Kapuścinski is prepared for the cinnamon shops to have vanished, but not for the possibility that they never existed. Schulz's world has disappeared, and yet its material remains are there to be found, in his stories and in the town of Drohobycz, even as these two remnants fail to converge. The momentary confusion of Schulz's real life with his fictional works happens because both refer to the past, and are thereby rendered parallel, as kinds of knowledge of uncertain status. The disorientation, however, is magnified by yet another shock:

Everything is so unclear, so inconceivable. Schulz wrote Cinnamon Shops in 1933. This was the worst year of the Great Hunger in the Ukraine, and thus not far from Drohobycz. Schulz surely did not know about this tragedy, so well concealed from the world. But what kind of forces are at work here, what currents, what undetected

obiadu o zapachu dzikim i polnym." (Bruno Schulz, The Street of Crocodiles [1933], trans. Celina Wieniewska, New York, Penguin Books, 1977, p. 25)

9. “'̇ycie wielkiego Schulza upłynęło więc w tym małym miasteczku, a nawet w zupełnie małym trójkacie między Floriańską, Zieloną i skwerem przy piekarni. Dzisiaj ludzie mogą przejść tę trasę w kilka minut, zastanawiając się nad tajemnicą niezwykłej wyobraźni Schulza.” (Ryszard Kapuściński, Imperium, p. 292; our translation).

10. "Dlatego zupełnie niedorzeczne jest moje pytanie: Panie Alfredzie, a w którym miejscu były sklepy cynamonowe? Szrejer przystaje, w jego wzroku jest mieszanina zaskoczenia, ironii i nawet nagany. Gdzie były sklepy cynamonowe?, powtarza. Przecież one były w wyobraźni Schulza! Tam świeciły. Tam pachniały w taki niepowtarzalny sposób! [...] Te suche badyle, które pan widzi ? [...] Czy mogła tu mieć swoje łóżko ta zidiociała dziewczyna Tłuja? Może mogła mieć." (Bruno Schulz, The Street of Crocodiles, p. 292-293; our translation) 
associations, relations, and oppositions, that make it so his book begins with such a grand, intoxicating vision of satiety? ${ }^{11}$

Most difficult for Kapuściński to apprehend of all is that the fact of history - the hunger and death caused by the Soviet Union-is nowhere to be found in the scene of Adela's return from the market in "August." The famine is unrepresented, more absent than Schulz himself or than his fictional world. But why should this finding - that a history, verifiable beyond a doubt, happens to be contradicted by a story-be more affecting than concrete evidence, the full account of the Ukrainian nightmare already given by Bronisława? He has already found its traces. Why then be troubled by not finding it in Drohobycz-or, rather, in a story written in Drohobycz, a story whose own past reality proves so difficult to verify?

Kapuściński's shock results not so much from the fact that absence may be more difficult to account for than presence. Rather, absence and presence, disappearance and appearance, become indistinct. In Drohobycz, historical sequence and historical concurrence break down, while the detail of daily life captured in fiction (the maid Adela as Pomona, the Roman goddess of orchards, returning from the market) fails to converge with history and geography (the concurrent events of a famine and of a child's joy at the sight of bountiful food, separated only by a short distance). What Kapuściński sees fails to match what he knows.

Such a moment of disorientation-true to disappearance-occurs because he attempts to revisit discordant objects of the past in person, to see them for himself, to ground them in the material world he witnesses. Schulz's failure to represent all of these objects at once-and Drohobycz's failure to show traces of them all-proves baffling because Kapuściński attempts to force an encounter between the distinct personae inhabiting the small town, and tries to impose order on the incongruous registers and temporalities that he knows, in a sense, coexist in this place. But they cannot all be rendered visible simultaneously. They are determined by intractable and multiple sources of knowledge of uncertain status.

11. "Wszystko jest takie niejasne, takie niepojęte. Schulz pisał Sklepy cynamonowe w 1933 roku. Był to najstraszniejszy rok Wielkiego Głodu na Ukrainie, a więc niedaleko od Drohobycza. Schulz o tej wielkiej tragedii, tak skrywanej przed światem, z pewnością nie wiedział. Ale jakie działają tu siły, jakie prą̧dy, jakie nie znane nam skojarzenia, związki i opozycje, ze jego książka zaczyna się wielką, odurzająca̧ wizją sytości?” (Ryszard Kapuściński, Imperium, p. 293; our translation). 


\section{OBSOLESCENT ETHICS}

Disappearance is an ambivalent guide. If to disappear means both to cease to be seen and to cease to exist, then disappearance admits the possibility of a lag between when an object passes out of sight and when it passes out of existence altogether. Taking the disappearance of the Soviet Union literally means opening the possibility of disorientation. It forces the mind to return and return to the time before disappearance, a time when the Soviet Union did exist, to ask what difference it made and how it shaped daily life. Attempting to verify what vanished with it and what has been left behind - not in a balance sheet, not as a record of a stage of transition-makes it clear that there is no clean break between before and after. And so we must not look for clean breaks - and it will not be out of a simple nostalgia, or mere attachment to the past because it happens to be our own, but out of fidelity to disappearance as such.

In Dreamworld and Catastrophe, Susan Buck-Morss does not hide her disappointment with the immediate aftermath of the Soviet Union's demise:

The revolutions of 1989 were in fact no revolution at all. [...] The real surge of critical political energy, including the great dissident literature, belongs to the period before the fall of the Wall. The dissolution of critical thinking began almost immediately thereafter, and it is striking how little original thought subsequently emerged. There was no widespread intellectual renaissance, no cultural rebirth, but rather a recycling of earlier dissident literature. ${ }^{12}$

The political and economic changes, for her, should have engendered new cultural forms - as if the Soviet Union was supposed to have taken all of its effects and displacements with it, rendering obsolete anything that failed to disappear along with it. The response to this circumstance is read under the sign of inadequacy, and the post-Soviet world seen as unable to produce new ideas. The frustrated expectation of rebirth turns into an accusation: culture lags behind history, fails to keep up with the times. But what if we reverse the direction, and look at culture's lagging or not lagging behind, rather than at objective political events. The fate of objects-both ordinary and aesthetic - and of the values attached to them may be instructive in finding a different account of historical change, one that, grounded first in the sensory and the everyday, takes the vicissitudes of disappearance as a guide.

Zbigniew Herbert's “Elegy for the Departure of Pen, Ink and Lamp” (1990) may be read as a response to a charge such as Buck-Morss's. Published, it seems, at the very brink of the Soviet Union's disappearance, the poem offers a plea

12. Susan Buck-Morss, Dreamworld and Catastrophe: The Passing of Mass Utopia in East and West, Cambridge, Massachusetts, MIT Press, 2000, p. 228-229. 
against abrupt judgments. The speaker is skeptical about the view of history as propelled by an impersonal force imposing arbitrary laws:

I never believed in the spirit of history

an invented monster with a murderous look

dialectical beast on a leash led by slaughterers

nor in you-four horsemen of the apocalypse

Huns of progress galloping over earthly and heavenly steppes

destroying everything worthy of respect old and defenseless ${ }^{13}$

Instead, the forward movement of history entails leaving behind small things, especially when they are not yet ready to be abandoned. The old-fashioned pen, ink and lamp of his childhood_the poem's addressees-did not simply depart but were discarded. Because of his own implication in their disappearance, the speaker has no recourse to simple nostalgia or mourning. He addresses his "dear companions" in order to issue a warning:

Lightheartedly we leave the gardens of childhood gardens of things

shedding in flight manuscripts oil-lamps dignity pens $[\ldots]$

I paid for the betrayal

but I did not know then

you were leaving forever

and that it will be dark ${ }^{14}$

The poem may at first appear merely nostalgic, tinged as it is with childhood innocence and with regret, but it refuses to treat the disappearance of the "dear companions" as a simple passing away that could be explained by the exigencies of history. It is, instead, oriented toward the future, as a warning about what is to come-the free market, perhaps, or the pressure to keep up with the timeswhich will render still-useful things disposable and replace them with "arrogant objects / without grace / name / or past."15 The locus of ethical resistance is in small things.

13. "Nigdy nie wierzyłem w ducha dziejów / wydumanego potwora o morderczym spojrzeniu / bestię dialektyczną na smyczy oprawców / ani w was-czterej jeźdzcy apokalipsy / Hunowie postępu cwałujacy przez ziemskie i niebieskie stepy / niszcza̧c po drodze wszystko co godne szacunku dawne i bezbronne." (Zbigniew Herbert, Poezje Wybranel Selected Poems, trans. John and Bogdana Carpenter, Kraków, Wydawnictwo Literackie, 2003, p. 172-181)

14. "Lekkomyślnie opuszczamy ogrody dzieciństwa ogrody rzeczy / roniąc w ucieczce manuskrypty lampki oliwne godność piora [...] zapłaciłem za zdradę / lecz wtedy nie wiedziałem / że odchodzicie na zawsze / i że będzie ciemno"

15. "Aroganckich przedmiotów / bez wdzięku / imienia / przeszłości" 
"Elegy for the Departure" raises the possibility that aesthetic objects and ethical values may be subject to the same process of abandonment as ordinary things. "There are still so many good thoughts in you," the speaker addresses the old inkwell in an apology. The poem may be read as a protest against viewing obsolescence as an objective condition-and, perhaps, against Herbert himself being too readily consigned to the past. For an assault on things "small / warm / faithful"16 did come, not only from outsiders who aided economic and political restructurings after 1989, or from well-meaning if disappointed Western critics, but also from within. In Poland, for example, the brulion group of poets, named after a journal launched in 1986, challenged the primacy of dissident tradition and the weight of messianic views of the nation. They gave voice to the desire "to establish a normal state and a normal society, and have normal earnings and normal inflation, as well as a normal literature that no longer had anything to do with ethics, politics, or theology."17 Their attack was aimed precisely at writers like Herbert, whose own earlier work-according to the logics of progress, of the clean break, and of direct relation between politics and aesthetics-should have quietly given way to new ideas by 1989. "Elegy for the Departure" warns against a naïve view of history as an inexorable force and protests against lighthearted abandonment of ordinary objects, for they have come to be invested with ethical values. A much earlier poem by Herbert, "The Envoy of Mr. Cogito" (1974) - a manifesto of the kind of austere ethical values associated with anti-Soviet resistance-is itself an object threatened with disposal. It is addressed directly to the reader:

Go where those others went to the dark boundary

for the golden fleece of nothingness your last prize

go upright among those who are on their knees $[\ldots]$

you were saved not in order to live

you have little time you must give testimony $[\ldots]$

and do not forgive truly it is not in your power

to forgive in the name of those betrayed at dawn ${ }^{18}$

16. "małą / ciepłą / wierną"

17. Piotr Śliwiński, "Are Things Worse or Is This Normal? Polish Poetry in the 199os," The Chicago Review, Vol. 46, No. 3-4, 2000, p. 340.

18. "Idź dokąad poszli tamci do ciemnego kresu / po złote runo nicości twoją ostatnią̧ nagrodę / idź wyprostowany wśród tych co na kolanach [...] / ocalałeś nie po to aby żyć / masz mało czasu trzeba dać świadectwo [...] / i nie przebaczaj zaiste nie w twojej mocy / przebaczać w imieniu tych których zdradzono o świcie" 
The ethical injunction is both absolute-such a life carries no earthly rewards except "the whip of laughter" and "murder on a garbage heap" - and impossible to follow to the letter, addressed as it is to the average person. Without a hope of consolation, one must "repeat old incantations of humanity fables and legends" in order to be "admitted to the company of cold skulls." mand, fit for a solemn time. But what would it mean to follow it once the Soviet Union has disappeared, to be righteous in a time of the free market? When there is no longer a Soviet Union, the kind of ethical corruption it enforced seems to have disappeared as well. This is how "The Envoy," an object mistakenly affixed to the time of the Soviet Union, comes to be declared obsolete.

A tentative literary history of the first post-Soviet decades already exists, tracking the fate of dissident ethos as it moved out of favor in the late 1980s and back to reverent popularity by the end of 199os-avant-garde revolt followed by the cooling of passions, an experiment with freedom giving way to a reconciliation between the old and the new. ${ }^{20}$ Such a literary history attempts to account for the sentiment that, with the dismantling of the Soviet State, "the past fell to pieces and became extinct," that millions of people "lost their future because they lost their past," and that "history left no time for preparation," ${ }^{21}$ but it must also account for the fact that the past turned out not to be lost after all. It partakes first of the notion of collapse (to avow a sudden break) and then makes use of the notion of transition (to explain the unexpected persistence of the past).

Read together, Herbert's "Elegy for the Departure" and "The Envoy" can help resist such a linear-if fraught-narrative. The poems suggest that ordinary things, aesthetic objects, and ethical values do not simply pass away on their own, but have to be discarded. If a poem such as "The Envoy" itself could be taken for an object firmly lodged in the Soviet past, then its refusal to vanish along with the Soviet Union-the object that appears to have produced it-may be considered a sign of cultural lack, of an inability to move on. Such a judgment, precisely, is what the later "Elegy for the Departure" contests. Thus, the apparent void of original thought after 1989 was not simply a space filled by recycled dissident ideas. Instead, it was a space of intense negotiation of ways in which culture

19. "Chłostą śmiechu zabójstwem na śmietniku [...] powtarzaj stare zaklęcia ludzkości bajki i legendy [...] idź bo tylko tak będziesz przyjęty do grona zimnych czaszek"

20. Krzysztof Koehler, "Carrying the Burden of Freedom: Some Thoughts on Polish Literature after Ten Years of Freedom," Toronto Slavic Quarterly, No. 3, winter 2003, http://www.utoronto.ca/tsq/o3/koehler2.shtml.

21. István Rév, Retroactive Justice: Prehistory of Post-Communism, Stanford, Stanford University Press, coll. "Cultural Memory in the Present", 2005, p. 8. 
ought to reconstitute itself after one of its major reference points - and one of its major constraints-disappears.

\section{ILLEGIBLE GHOSTS}

The ambivalent dynamic of disappearance may best be captured not in a dialogue staged between literary traditions, but in a film, which can render visible what may be on the verge of vanishing. Krzysztof Kieślowski's No End (Bez końca, 1984) documents a moment of heightened cultural crisis prompted by the imposition of martial law in Poland after the Solidarity movement's defeat. The film's story begins a few days after an idealistic lawyer, Antek Zyro, dies of a heart attack. He leaves behind a grieving widow and a client, Darek, a young factory worker due to stand trial for organizing a strike. Darek's friends manage to enlist the apolitical, mournful widow Ula in finding a lawyer trustworthy enough to continue the defense. Labrador, Antek's old teacher, agrees to take on the job. The film's attention is divided between Ula's private mourning and the political events in which her husband had been involved, with Antek's ghost watching over everyone like a guardian angel.

No End portrays a clash between two impossible ideals produced but not completely determined by the Soviet Union. The first of these ideals, state socialism, is treated as legitimate by the courts. Antek embodies the second ideal, that of uncompromising resistance, even as this embodiment takes the form of a barely-legible trace after his death. The struggle between these ideals takes place on the ground of the juridical, as well as on the ground of Darek's body as he engages in a hunger strike in prison.

The film itself reflects on the making of history from within, without the benefit of knowing the outcome-the eventual demise of the Soviet system. Thus, it works like a historian who, "by recording concurrent events which [...] sometimes lack apparent connections, [...] might be able to restore the uncertain, open quality of history as experienced in eventu." ${ }^{22}$ With the benefit of hindsight, it may be tempting to say that, with the impending fall of the Soviet Union, the characters are merely waiting for history to take its course. In such a reading, their ethical dilemmas may seem artificial because they are attached to the Soviet Union, whose fall will render them definitively obsolete. The characters may seem like puppets, living an illusory life not of their own making. As a record of "history as experienced in eventu," however, No End attends to various modes 
of the Soviet Union's appearance-in State-socialist ideology on the one hand, and in dissident ethos on the other-at the same time as it shows these modes to be already in some sense ghostly - not because they are about to disappear, but because both are impossible to realize, or to make apparent, to the letter.

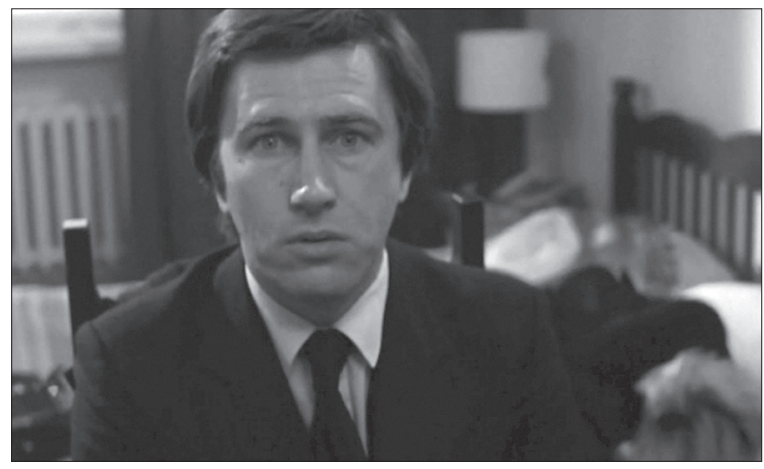

Fig. 1. "I died:" Antek (Jerzy Radziwiłowicz) addresses the viewer, with Ula asleep in bed. Krzysztof Kieślowski, No End (Bez końca, 1984).

(C) Courtesy of Kino International.

Antek haunts the film in his ghostly incarnation, by appearing on the screen to the viewer. (fig.1) To the characters, he is visible only twice: when Ula's visit to the hypnotist, who offers to help her forget her husband, turns instead into a séance, a conjuration of the dead; and at the end of the film, when the courtroom empties out after Darek's trial and the defendant suddenly notices Antek's presence. Antek also haunts the film in his legacy, acting as an embodiment of resistance and arbiter of integrity even after his death. The question of what Antek would have done were he alive is a common reference point. His righteousness-reminiscent of Mr. Cogito's in its austerity-is taken for granted yet, for the viewer, there is little direct access to his actual ethical principles. Antek cannot give account of them himself; instead, they are made apparent in halfpronounced hints, sometimes mediated by Ula's unreliable translation. At one point, she tries to decipher Antek's notes on the case, but can make out only inconclusive fragments: "if the law turns against community, loyalty or trust, it is... immoral" and "the law... kills what is most precious among people." "Here's a question mark... or an exclamation point," she says uncertainly, and confesses 
to Labrador: "I could never read him."23 (fig. 2) Another time, an old friend tells Ula that Antek always wanted to be free. "Was he?" she asks, as if she had given little thought to her husband's work.

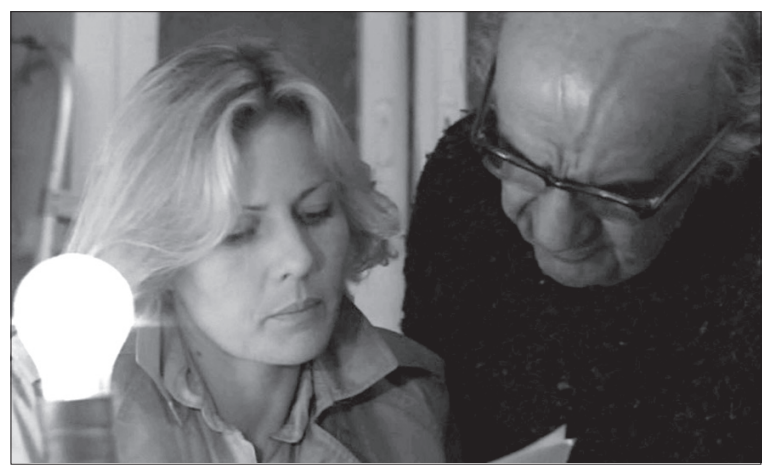

Fig. 2. Ula (Graźyna Szapołowska) reads Antek's notes on the case to Labrador (Aleksander Bardini). Krzysztof Kieślowski, No End (Bez końca, 1984). (C) Courtesy of Kino International.

The answer to what Antek would have done comes most clearly in the figure of Darek, who invokes him at every turn to defend himself from the threat of compromise. Yet the deceased lawyer's ethical principles come to be increasingly difficult to decipher and confused even here, as Darek attempts to remain faithful to him by refusing all the options offered him. "Mr. Zyro said I wouldn't have to do this," Darek protests at the idea of pleading ignorance. "He said one must find one's own way," he insists when he's asked to claim an extreme political position. Darek says he never wanted to smash the State. He just wanted to make Poland a better place for everyone. "Which Poland do you mean, son?" old Labrador asks. "Our Poland-there's no other one," Darek replies, forced to concede that he cannot imagine a Poland other than the socialist one. ${ }^{24}$

23. "Jeśli prawo jest przeciw wspólnocie, lojalności czy ufności jest niemoralne"; "Prawo zabija to co najcenniejsze między ludźmi"; "Znak zapytania czy wykrzyknik... nigdy nie mogłam go odczytać." (Our translation)

24. "Mecenas Zyro powiedział, że nie będziemy robić takich rzeczy"; "Każdy musi sam znaleźć drogę"; "W jakiej Polsce?"; "W Polsce-w naszej. Nie ma innej." (Our translation) 
The verdict in Darek's case is a suspended sentence-a limbo, neither a defeat nor a victory. It may have been easier and more dramatic to be punished. Attempting to be faithful to Antek's legacy, Darek is denied the reward of unequivocal resolution because everyone involved wants most of all to survive and to retain dignity. There is no uniformity of response in No End, no common values, as every character offers a different version of what it means to live in such a time and place. Antek is a common reference point, but he fails to make coherent the communities he has left behind.

Susan Buck-Morss has written that, "told as an economic story, the collapse of Eastern European and Soviet socialism loses its heroic dimensions, becoming yet another chapter in the general narrative of global industrialism."25 But the ethical and the aesthetic dimensions of anti-Soviet resistance are not suddenly rendered profane when juxtaposed with the economic. The fate of material things is connected to that of ethical values and aesthetic objects. "The day I can buy toilet paper in a Polish store, I'll discuss politics," Kieślowski once said. ${ }^{26}$ Dissident ethos was never a matter of mere poetry. It was always grounded in the everyday struggle to maintain integrity.

Accounting for disappearance demands a confrontation of incongruous elements, forces an interaction between distinct personae that inhabit a time and a place. Declaring that objects grounded in the Soviet past are necessarily obsolete-declaring, that is, a definitive historical rupture-entails an exorcism of ghosts such as Antek's. If to disappear means to vanish from sight and/or from existence, then the film (like, perhaps, all films) effects a contradictory movement: it shows what has disappeared; it thematizes death and mourning even as it brings Antek back to life; it mobilizes the visible only to undermine certainty. And if, in turn, to disappear is taken in its transitive sense-to render something invisible or nonexistent-then the film refuses to participate. The Soviet Union has left behind an organization of values of different registers, vested in objects of different orders of materiality.

Its disappearance demands the recognition that the objects thus inflected may outlive their cause.

25. Susan Buck-Morss, Dreamworld and Catastrophe, p. 263.

26. Quoted in Annette Insdorf, Double Lives, Second Chances: The Cinema of Krzysztof Kieslowski, New York, Miramax Books, 1999, p. 68. 